\title{
Functional Expense Allocation Ratios to Predict Financial Condition at Public Higher Education Institutions
}

\author{
Cassandra Bennett \\ Bloomsburg University \\ Mark Law \\ Bloomsburg University
}

The higher education industry has faced increased competition in recent years from new institutions and learning platforms entering the marketplace. Public higher education institutions, in particular, have been forced to develop strategic plans due to limited state funding in recent years. These colleges and universities face the challenge of allocating their limited financial resources in a manner that will optimize financial strength and ensure long-term sustainability. Institutions classify their operating expenses into several different functional expense categories, including instruction, academic support, student services and operations and maintenance of plant. This paper analyzed the relationship between allocation ratios of functional expenses and an institution's financial condition. Multiple regression analysis was performed to determine how fluctuations in financial allocation ratios impact an institution's financial condition. The research could aide higher education institutions in strategically allocating resources to improve their financial position.

Keywords: functional expense allocation, financial condition, public higher education

\section{INTRODUCTION}

The strategic allocation of financial resources is important in any industry; however, it has become an essential part of higher education as colleges and universities vie for students. Faced with limited state funding, Public State Systems of Higher Education are struggling to survive making effective investment decisions necessary. It is important to understand the relationship between the allocation of financial resources and their impact on an institution's financial condition. Insight into these relationships is critical to the survival of public higher education institutions.

State Systems of Higher Education Institutions across the United States have experienced a budget crisis over the past decade (Klein, 2015). The decline in the number of high school graduates in recent years coupled with minimal increases in state funding are main contributing factors. According to the December 2016 Western Interstate Commission for Higher Education (WICHE) report, the number of high school graduates in the United States is expected to be lower between 2013 and 2023 than the record high of 3.47 million in 2013 (Bransberger \& Michelau, 2016). In the past few decades, state governments across the United States have considerably reduced funding of public higher education institutions (Klein). In fact, currently the amount of state funding per student for public higher education is less than it was in 1980 
(Klein). According to Sav (2016), state appropriations as a percentage of total public college and university revenue declined from $32 \%$ in 2004 to $23 \%$ in 2013. Many state systems have been forced to compensate for the shrinking state appropriations through increased tuition costs for students, reduction in financial aid and a decline in faculty salaries (Weerts, 2014). For example, the State University System of Florida raised tuition by 32\% from 2009-2011, while Minnesota State Colleges and Universities System eliminated financial aid grants to approximately 9,400 students (Altundemir, 2012). The North Carolina State University eliminated 187 full-time equivalent positions during the 2014 academic year (Mitchell, Palacios, \& Leachman, 2014). Many state systems have implemented similar initiatives to counteract the reduction in state funding. The sustainability of public higher education systems has become questionable and many of them are seeking guidance to develop strategic plans for long-term viability.

Colleges and universities face the challenge of allocating limited financial resources in a manner that will optimize profitability and improve sustainability. The decline in state appropriations may affect how these institutions allocate financial resources to specific functional categories. Institutions classify operating expenses into several different functional categories "according to the purpose for which the costs are incurred" (Phillips \& Olson, 2015, p.119). These categories help donors, creditors, and users of the financial statements grasp the different goals and activities of an institution and their role in its overall mission (Phillips \& Olson). Examples of functional areas include instruction, academic support, student services and operations and maintenance of plant. This study analyzed the financial statements of each four-year institution within a public higher education system in the South Atlantic region of the United States to identify the impact of changes in state appropriations levels and financial allocation ratios of functional expenses on financial condition of the institution.

\section{PROBLEM STATEMENT}

The problem addressed was the lack of a defined methodology in the allocation of financial resources among State Systems of Higher Education institutions given a decline in state appropriations per student resulting in financial distress. Tasked with providing education to its citizens with limited state support and minimal tuition increases, public institutions have been faced with critical decisions. Some institutions are considering or have already begun implementing changes, including "academic reorganization (closing departments or entire campuses), curtailing student enrollment, layoffs, greater teaching workloads, and position eliminations" (Altundemir, 2012, p. 193). For instance, faculty at Minnesota State Universities agreed to a pay freeze during the 2009 academic year (Severns, 2012), the University of Florida cut 261 positions for full-time tenure and tenure-track faculty from 2007 to 2011 (Mitchell et al., 2014), and the University of Idaho has imposed furlough days on 2,600 state-wide employees (Altundemir). It is essential for public higher education systems to develop a methodology for allocating resources to ensure their survival.

\section{PURPOSE STATEMENT}

The purpose of this quantitative correlational study analyzed whether the allocation ratios can be used to predict the financial condition of an institution. Understanding the relationship between allocation ratios and financial condition can provide valuable information to government officials as well as institutional leaders. In addition, the data can provide invaluable information to administrators of public institutions to develop budgets that reflect efficient and effective resource allocation. Budgets explain how resources are allocated to optimally meet an institution's goals and objectives (Palmer, 2014). The functional areas of an institution, such as instruction, academic support, student services and operations and maintenance of plant, reflect the purpose of the expenses and activities in which the college or university invests. Understanding the degree to which these functional areas contribute to an institution's financial health could be the key to long-term survival. State Systems of Higher Education can utilize this information in strategic planning models to develop efficient and effective methods for allocating resources to ensure institutional sustainability. 


\section{NATURE OF THE STUDY}

A quantitative correlational study was conducted and was considered appropriate given the research included historical financial data from institutions within a state higher education system in the South Atlantic region of the United States. Quantitative research uses numbers and closed-ended questions to analyze relationships among the data (Creswell, 2014). The audited financial statements of each four-year institution in a state system in the South Atlantic region of the United States for academic years 2008 through 2017 was obtained through the state system website. Unrestricted net assets and functional expense amounts for each year were summarized in an Excel spreadsheet.

Correlational design was chosen since the purpose of the study was to discover whether changes in allocation ratios can predict financial condition. The research analyzed the relationships among the percentage changes in allocation ratios of functional expense categories and the financial condition of these Public State System Institutions. Frequency counts, percentages, chi-squares, t tests, ANOVAs, MannWhitney U-test, Wilcoxon signed ranks test and regression analysis are all tools which can be used to perform a quantitative study (Pionsky \& Gass, 2011). Multiple regression is most appropriate for a correlational design since it can be used to evaluate whether certain independent variables can predict a dependent variable.

Regression analysis is a statistical tool used to analyze the relationship between a dependent variable and one or more independent variables (Ragsdale, 2015). The goal is to identify a function to describe the relationship among variables which can be used to predict the value of the dependent variable given specific values of the independent variables (Ragsdale, 2015). Multiple linear regression analysis was appropriate for this study given the purpose was to determine whether changes in allocation ratios can also be used to predict financial condition. Once the multiple regression models were completed, the data were analyzed to identify if any patterns exist.

\section{RESEARCH QUESTION}

The research analyzed the data to determine whether there was a correlation between the independent variables (financial allocation ratios of functional expense categories) and the dependent variable (financial condition of an institution). If it is determined that the financial allocation ratios can help to predict financial condition, administrative personnel at public higher education institutions can apply the findings to the planning and budgeting processes. The research question to be addressed is:

1) Is there a correlation between the allocation ratios of an institution, individually or in combination, and its financial condition?

The allocation ratios in the study were computed by dividing a functional expenditure category by Total Operating Expenditures (TOE) to form a percentage of TOE (Kempton, 1996). The allocation ratios were as follows:

- Instruction/TOE

- Research/TOE

- Public Service/TOE

- Academic Support/TOE

- Student Services/TOE

- General Institutional Support/TOE

- Operations and Maintenance of Plant/TOE

- Student Financial Aid/TOE

- Auxiliary Enterprises/TOE

- Depreciation/TOE

- Other/TOE

For purpose of this study, the financial condition of an institution was measured by the percentage of unrestricted net assets maintained (Kempton, 1996) which is the accumulated amount of excess revenues 
over expenditures in a governmental fund (Kelly, 2013). The unrestricted net asset balance is often used as an indicator of financial condition by potential creditors, financial analysts, and state agencies (Kelly).

Financial $\quad=\quad$ unrestricted net assets $\quad \mathrm{X} \quad 100$

Condition TOE

Percentage

Based on the definition of financial condition noted above, institutions with larger financial condition ratios have a higher percentage of unrestricted net asset balance and will have the ability to finance its operations through its savings (Kelly, 2013). Institutions with higher financial condition percentages indicate stronger financial position.

\section{HYPOTHESIS}

The following hypothesis generated the problem inherent in the study and was tested empirically:

H1 $_{0}$ : There are no statistically significant associations among allocation ratios of functional expenses and financial condition.

\section{SIGNIFICANCE OF THE STUDY}

The research performed in this study can provide state system colleges and universities with strategies for allocating funds to the functional areas with the greatest benefit to enable them to survive the tumultuous times of the higher education industry. Consequently, the results may provide these institutions with the competitive advantage they need to provide a quality education at an affordable price.

\section{Reduction of Gaps}

Although there is research which describes investment decisions and their impact on enrollment and profitability at higher education institutions, a compilation of information from historical data and trends which dissects this information specific to public state higher education institutions is not currently available. Currently there are no predictors of financial condition identified for these institutions. The research could provide opportunities for colleges and universities to implement resource allocation techniques to ensure the sustainability of the institution. It is anticipated that the research will provide a forum which institutions can consult when determining how to allocate their limited financial resources.

\section{A REVIEW OF THE PROFESSIONAL AND ACADEMIC LITERATURE}

Today's global environment has created fierce competition among many industries, including higher education. The United States higher education system has enabled its citizens to better themselves in society by obtaining the knowledge and skills to develop products and services (Powell \& Rey, 2015). Although an education can provide students with abundant opportunities, many higher education institutions struggle to remain financially stable (Woodhouse, 2015). Tuition costs, online learning platforms, lower unemployment rates, and a decreasing number of high school graduates have threatened the survival of some of the brick and mortar institutions (Farber, 2016). Colleges and universities must identify ways to attract and retain students with limited financial resources. Public State System Institutions, in particular, face intense financial struggles due to the recent decline in state funding for higher education. Operating with finite financial resources makes it crucial for these institutions to allocate their funds efficiently and effectively to remain profitable and ensure their future success. Institutions should develop a strategic plan to define their direction for the future with careful consideration of how to optimally allocate their resources. 


\section{Functional Expenditures}

There are several ways in which public higher education institutions may choose to strategically allocate their financial resources. This study analyzes the allocation ratios based on functional expense categories. The Governmental Accounting Standards Board (GASB) develops standards and provides guidelines for financial reporting for all state and local government entities. GASB 34 (GASB, para. 41) requires government entities to report all expenses by function in its statement of activities. At a minimum, governmental entities are required to report all direct expenses, which relate to a particular service, program or department, by function (GASB, para. 41). The standards are intended to demonstrate government's accountability to the public by providing fund allocations (Voorhees \& Kravchuk, 2002).

Guidance for the classification of functional expenses for public higher education institutions is provided in the Financial Accounting and Reporting Manual (FARM) for Higher Education published by the National Association of College and University Business Officers (NACUBO). There are 11 major categories of functional expenses which include: instruction, research, public service, academic support, student services, general institutional support, operations and maintenance of plant, student financial aid, auxiliary enterprises, depreciation and other. Institutions may choose to allocate resources differently among each of the functional expense categories. Identifying the optimal resource allocation ratios which promote financial stability could assist in the budgeting process.

\section{Instruction}

The primary objective of a higher education institution is to educate its students. Instruction is one of the functional expense categories an institution may choose to invest. The instruction category includes activities related to an institution's academic, vocational, community education, remedial and tutorial instruction (FARM, para. 342.11). The cost of departmental research and public service are also represented in this category (FARM, para. 342.11). A major component of the instruction category relates to faculty salaries and benefits.

Faculty. Colleges and universities operate in the service industry which makes their employees a major asset. The theory of human capital recognizes employees as a valuable resource which if invested in can yield returns in the future (Nafukho, 2009). Faculty play a vital role in the success of colleges and universities because they are tasked with imparting their knowledge to students through lectures, reading and writing assignments, laboratory sessions and examinations (Mintrom, 2008). Their interactions with students can influence the overall campus environment. Although human capital can be a valuable asset to an organization, it is a risky investment because of the possibility of employee turnover. Colleges and universities must weigh the costs and benefits of human capital to decide whether investing additional resources in their employees is the right decision.

Deciding whether to allocate financial resources into attracting and retaining employees can be challenging. Faculty of colleges and universities contribute to the overall collegiate experience because they have direct contact with the students. The collective knowledge, skills and abilities of these employees is a critical component of student enrollment and thus it is important for institutions to measure this value and its contribution to the bottom line (Mello, 2015). Because human capital can provide higher education institutions with a competitive advantage, they "now need strategies and initiatives that will bring improvements through their greatest asset" (Broadhurst, 2012, p. 27). Most colleges and universities attempt to align faculty needs based on the mission of the institution (Zhang, Yu, Yang, \& Du, 2014). College and university administrators are constantly struggling to have the appropriate faculty in the right place at the right time (Khasawneh, 2011). To avoid talent deficits, colleges and universities should improve forecasting efforts of future talent needs using human capital planning (Khasawneh). Without the proper forecasting, universities can suffer the consequences of being overstaffed or understaffed and losing the talent necessary for a competitive advantage (Khasawneh). Providing quality educators that enhance the classroom experience can help satisfy student needs and contribute to the success of the institution. Public institutions can maintain quality faculty by attracting talented educators and expanding retention efforts of superior faculty members. These areas of investment can provide a valuable return by enhancing an institution's learning experience and increasing the overall quality of education it provides. 


\section{Research}

The research functional expense category consists of the expenses of producing research whether funded by an institution or external agency (FARM, para. 342.12). Because research-based knowledge is identified as a crucial component of economic progress, many colleges and universities are placing greater emphasis on their research activities (Mintrom, 2008). Publicly-funded higher education institutions have a responsibility to the public to provide access for all students while maintaining an excellent curriculum and contributing valuable research (Weerts, 2012). Despite the necessity of research, state funding for public research universities has decreased by an average of $34 \%$ over the past ten years (Weerts).

Research plays an integral part of society by expanding the current knowledge base. It promotes innovation and drives productivity forward. Public research institutions have made astonishing contributions to the healthcare and technology fields and enhanced the standard of living for Americans (Weerts, 2012). Increasing research productivity among colleges and universities can provide direct benefits to faculty members, departments and the entire institution (McGill \& Settle, 2012). Research has indicated that scholarly excellence can have a positive impact on an institution's reputation which can enable these colleges and universities to attract high-quality students and increase their ability to obtain external funding (McGill \& Settle). Instructors are tasked with conveying knowledge to their students; therefore, it is important for these individuals to stay abreast of developments in their respective field of study. Performing research and producing scholarly works allows faculty members to maintain expert knowledge and communicate this information in their classrooms.

Institutions may choose to invest resources into research support. Research support can take on several aspects, including time needed to produce scholarship, monetary funding to pursue research, and assistance and training necessary to produce quality scholarship (McGill \& Settle, 2012). Universities that consider research a critical component of its mission, carefully select employees based on their research capabilities and often offer incentives (such as monetary awards or release time) to staff members who generate scholarly works (Mintrom, 2008). Faculty are often evaluated for tenure status on the basis of their teaching skills, research productivity and service to the institution and community (Sanford \& Kinch, 2016).

\section{Public Service}

Public service encompasses non-instructional aspects of the institution and provides benefits to parties outside of the institution (FARM, para. 342.13). This category includes community service activities, not including instructional programs (FARM, para. 342.13). Public service has been revered as a core principle of higher education, alongside teaching and research (Lee, 2017). It is important for higher education institutions to improve the surrounding community in which they operate through various forms of public service. Colleges and universities have received recognition not only for their teaching and research accomplishments, but their service as well (Harris, 2008). Higher accountability standards have led higher education institutions to focus on demonstrating the tangible benefit they provide to their community (Harris). Colleges and universities are not only responsible for preparing students for employment and research, but also to contribute to society through public service (Ford, 2017).

Public service includes providing resources and support to human service organizations, hospitals and other non-profit organizations (Harris, 2008). The goal of public service is to make a difference in the surrounding communities by developing a combination of knowledge, skills and values (Harris). Community service, cooperative extension service, public broadcasting service and public service informational technology are all elements of the public service function (FARM, para. 342.13). When higher education institutions invest in these areas, it not only benefits the community, but enhances the purpose of the institution by increasing student and faculty engagement (Harris).

\section{Academic Support}

Academic support is a broad category that includes expenses which support the institution's overall missions: instruction, research and public service (FARM, para. 342.14). This function can be broken down into the following subcategories: libraries, museums and galleries, educational media services, academic support informational technology, ancillary support, academic administration, academic professional 
development and course and curriculum development. The library and informational technology provides a platform for students to further their education. Faculty professional development and course and curriculum development are also major components of the academic support function.

Library. Libraries provide a vast array of knowledge and information and provide a hub for research. Higher education libraries have taken on the role of information, communication and education centers (Mihaljevic, 2015). With the development of the internet and advancement in technology, most academic libraries have hybrid features. College libraries now include "licensed digital collections such as CDROMS, DVD, or locally loaded databases obtained from external sources" (Kibirige \& DePalo, 2001). They also provide remote access to internal and external databases through the Internet. Hard copy data are now developed into digital media files through the library function (Kibirige \& DePalo). Library staff also provide training programs for staff and students on the features of the digital databases and how to access and utilize them (Kibirige \& DePalo).

Informational Technology. Another area where colleges and universities can look to improve enrollment is investing in technology. As technology continues to develop, more efficient and effective software and equipment becomes available. Higher education institutions can utilize this technology to aide in educating its students. By providing advanced technology and enhancing education quality, institutions can expand their student enrollment rates and improve financial health. Just as companies in today's competitive business environment must have the ability to adjust their strategies in response to their competitors in order to survive and maintain a competitive advantage (Kengatharan, 2016), colleges and universities must adapt to new technology if they wish to survive. Information technology covers a vast array of support for academia, including learning platforms (course management systems), distance education and classroom technology.

Faculty Development. Higher education institutions may choose to invest resources into developing research and teaching skills of its faculty. Due to increased competition in the higher education sector and "demands for public accountability and improved teaching and learning, institutions are recognizing the need to strengthen their faculty development programs" (Lowenthal, Wray, Bates, Switzer, \& Stevens, 2012, p. 149). Employee development is critical to furthering the skills and knowledge of not only individual employees, but also the organization as a whole (Chay Hoon \& Bruvold, 2003). Faculty development has become a major focus over recent years. The faculty workload has increased to include teaching, scholarship and service while assessment guidelines have grown more prominent and often drive state funding (Carpenter, Sweet, \& Blythe, 2016).

Faculty development has evolved from simply sabbatical leaves to include a wide variety of program offerings covering topics from scholarly research to teaching strategies (Austin \& Sorcinelli, 2013). Today, expectations of faculty are high as administrators believe they should be adept researchers as well as skilled educators (Lowenthal et al., 2012). It is presumed that because faculty possess a terminal degree, they are expert educators; however, institutions must provide teaching tips and training sessions to these individuals to enhance the student learning experience. Investing in faculty development is a crucial factor in allowing institutions to maintain quality standards and support changes in higher education (Austin \& Sorcinelli).

Course and Curriculum Development. The development and implementation of new academic programs is another element of the instruction category. Institutions can invest in these programs to attract new students and enhance their overall mission. Administration and faculty must work together to identify potential majors and minors that may appeal to today's college students. Many institutions may go through a detailed analysis of their existing academic programs to identify areas of weakness and consider reallocating assets and faculty to new academic programs.

Colleges and universities must also keep abreast of the changing needs of employers to determine demand for college graduates. Many institutions have developed majors and minors to meet industry needs and technological advancements over the past ten years. Extensive data, including labor market demand for graduates and the resources necessary for implementation should be carefully considered among proposals for new academic programs (Dee \& Heineman, 2016). Institutions that can identify these emerging areas and provide the required education for their students to obtain these jobs can gain a competitive advantage over other institutions. 


\section{Student Services}

The student services category includes expenses incurred for activities which contribute to students' emotional, intellectual and physical well-being outside of formal instruction (FARM, para. 342.15). This includes subcategories, such as the offices of admissions and financial aid as well as student life/activities (FARM, para. 342.15). Student life/activities which stimulate social and cultural development consists of student organizations, both intramural and intercollegiate athletics, health services and outdoor activities.

Admissions. Staff can also play a major role as a profit generator for a college or university. They may have direct contact with students and contribute to the overall collegiate experience. Today, students face complex issues; therefore, student service staff must be innovative to meet student needs and gain a competitive advantage (Felix \& Lerner, 2017). Staff members in the admissions area are primarily responsible for attracting new students. They reach out to prospective students through presentations, tours, administrative tasks and working with faculty and staff members to promote their institution (GansemerTopf, Von Haden, \& Peggar, 2014). Their success in recruiting and ability to meet enrollment numbers directly influences gross tuition revenue which is critical to an institution's success (Gansemer-Topf et al.). Although admission counselor positions are generally entry-level positions, they require professional skills such as business and marketing as well as knowledge of institutional policies (Gansemer-Topf et al.). Colleges and universities need to recognize individuals with this valuable skillset because those that have significant turnover or disruption in this area can feel a negative ripple effect on their income statement as gross tuition can be impacted in a negative way.

Financial Aid. Financial aid staff are tasked with determining the amount of financial aid for which the students are eligible. They serve as a resource for students to help them understand how they are going to pay the cost of college (McKinney \& Roberts, 2012). As costs for attending college continue to rise, additional pressure is placed on financial aid to properly balance the overall price of college for students with generating the desired amount of net tuition revenue necessary for the college or university to meet budgeted figures. Financial aid packaging for admitted students can require a level of skill and expertise in order to attract the required number of students without providing financial aid in excess of budgeted amounts. These counselors also help students complete the necessary paperwork, such as the FAFSA, loan and scholarship applications and identify alternative sources of financial aid (McKinney \& Roberts). Colleges and universities can suffer financially without this level of knowledge and proficiency in this department.

Student Life/Activities. Colleges and universities may also consider focusing resources on enhancing the student life environment. Identifying the preferences outside of the classroom for the incoming generation of prospective students can be a key recruitment and retention tool. A prospective student's ability to relate to activities and organizations is important to them.

Higher education institutions can focus on maintaining student organizations, athletics, health services as well as outdoor activities in an effort to attract students. Although colleges and universities cannot directly influence a student's ability to flourish, they can create a positive environment to enhance the collegiate experience (Marks \& Wade, 2015). In order to develop new programs and activities, administration has to evaluate the current student life programming and reallocate resources where necessary to invest in programming that is attractive to the new generation of students.

\section{Institutional Support}

Institutional support refers to expenses for activities which involve long-term planning for the entire institution (FARM, para. 342.16). This is an important category which relies heavily on several layers, including executive management, fiscal operations, general administration, administrative informational technology and development (FARM, para. 342.16).

Executive Management. The executive management function is responsible for guiding the overall direction and mission of the college through long-range strategic planning (FARM, para. 342.16). Executive management includes the duties of the individuals, such as the president, provost, chief business officer, chief student affairs officer and chief development officer (FARM, para. 342.16). With changes to the higher education sector over the past 20 years, including increased competition, accountability and 
restructuring has placed greater responsibility and importance on the executive management team (Jones, Lefoe, Harvey, \& Ryland, 2012). Higher education institutions must invest in developing sustainable leadership because they are tasked with the unique role of developing new knowledge and delivering existing knowledge to its students (Jones et al.)

Fiscal Operations. Fiscal operations relates to financial activity of the institution and is typically housed within the business office. Employees in the business office primarily monitor the expenditures of the institution. The budget monitoring process is an important tool that provides management of the college or university the information that they need to make "real-time" decisions related to future expenditures. The role of the bursar in the business office can also have a major impact on tuition, room and board revenue. The bursar is in charge of billing students and collecting payments (Felix \& Lerner, 2017). Colleges and universities can incur substantial losses related to writing off uncollectible accounts if the billings and collections process is not managed properly.

General Administration. Administration activities of a college or university, excluding informational technology and fiscal operations, fall into the category of general administration (FARM, para. 342.16). Some examples of areas included in general administration are human resources, communication and transportation and print shops (FARM, para. 342.16).

Administrative Informational Technology. Administrative informational technology supports the overall campus mission, excluding technological support for academic activities. Technology used for marketing and campus infrastructure are two types which may be included in this category.

Development. The development function of a college or university is responsible for conducting activities to maintain relationships with alumni, the community and other groups. The primary purpose of these activities is to promote the college or university and build relationships in order to solicit support. As competition in higher education has grown, limiting the income streams (especially for public institutions), the development function has faced increased pressure to fundraise to ensure institutional sustainability (Daly, 2013). Typically, development seeks support that is financial in nature but it could also help to identify potential board or alumni committee members, enhance connections that would provide internships and future jobs for students, and recognize occasions where the college or university could support community events and organizations.

\section{Operations and Maintenance of Plant}

The operations and maintenance of plant functional classification encompasses expenditures related to operation, maintenance, supervision, administration and protection of the college or university's physical plant (FARM. para. 342.17). Typical types of expenditures that fall into this category consist of the following: repairs to the buildings, equipment and furniture on campus; custodial services for cleaning of the academic spaces as well as the residence halls; maintenance for all utilities for the buildings and other plant facilities; care of the grounds; hazardous waste disposal; facility planning and management and overseeing campus renovations and construction projects (FARM, para. 342.17).

Colleges and universities operate in a highly competitive marketplace; therefore, they face increased pressure to attract quality students (Roberts \& Taylor, 2016). One of the major branding tools institutions use to gain a competitive advantage are their buildings and overall campus appearance (Roberts \& Taylor). Campus facilities support the college or university's core functions, such as education and research (Kärnä \& Julin, 2015). Investing in the buildings which support academic growth and enhance the campus could help colleges and universities achieve optimal enrollment. Maintaining the plant and equipment on campus is an integral part of the overall process and facilities on college campuses last for many generations. The management of facility resources of an institution plays an important role in achieving its goals of providing a quality learning environment and a sustainable infrastructure for university functions (Kärnä, Julin, \& Nenonen, 2013). Recently, a majority of universities have realized the importance of improving the physical assets of the campus to address institutional objectives, such as attracting prospective students; enhancing the quality of life of current students, faculty and staff; fostering a learning environment; and creating a stable environment which benefits the surrounding community (Hajrasouliha, 2017). 
Despite the research that supports investing in buildings and capital projects throughout the campus, state systems have fallen behind when it comes to investing financially in these areas. In fact, the gross capital spending in higher education across all 50 states totaled $\$ 10.3$ billion in 2009 (Ness \& Tandberg, 2013). This only represents $13 \%$ of the state general fund appropriations and equates to approximately $\$ 700$ per student enrolled in Public State System Institutions (Ness \& Tandberg). Capital budgeting decisions are crucial to the future of higher education institutions since tuition discount rates are at record highs, and admission targets are becoming more difficult to maintain as enrollments drop (Staton, 2014). There are many capital projects higher education institutions may choose to invest in, including residence halls, academic buildings, landscaping, and student facilities.

Residence Halls. Residential halls are an important part of the overall college experience for students since it is where they will spend a majority of their time. Maintenance and cleanliness of the residence halls can play a significant factor in the students' satisfaction level and can impact retention. The features, types and variety of on-campus housing can play a major role in the overall campus experience (Jensen \& Winters, 2012). "Student housing has allowed community colleges to raise enrollment, increase revenue, add diversity and provide a complete college experience" (Aquije, 2011, para. 6). Many colleges must balance between the number of beds they have available and the types of rooms they offer while taking into consideration that many students choose to live off campus (Tietjen, 2015). Higher education institutions have many different options available for residential housing: traditional dorm style, suites and apartments.

The cost as well as the revenue generated from each type of housing option varies. Colleges and universities must also consider other qualitative factors when making a decision on which housing option to choose to add to their campus footprint. It is important to consider student preferences when choosing a housing model because it can expand an institution's enrollment. When all other aspects of colleges and universities are equal, prospective students have made their choice based upon the best housing options offered (McBride, 2017). Although certain models may generate more revenue per square foot, if they cannot attract prospective students and maintain capacity they should not be built. This is a constant struggle which most colleges and universities face today. Students and parents have become extremely selective and student housing can determine which college they will attend; therefore, investing in quality housing options can provide colleges and universities with a competitive advantage (Cheskis-Gold \& Danahy, 2012).

Academic Buildings. Another area of focus for plant improvement is academic buildings. Students spend a significant amount of time in the classroom; therefore, academic buildings support a student's educational experience. Academic buildings should provide a space to foster active and collaborative learning (Leather \& Marinho, 2010). "Buildings should contain teaching and learning spaces that enable highly interactive work, both formal and informal areas for students and faculty groups to gather and for students and faculty to meet with each other, and spaces for impromptu face-to-face and/or technologically mediated interaction" (Leather \& Marinho, p. 42). Academic buildings should also reflect the professional environments students will become a part of upon graduation (Leather \& Marinho). The cleanliness and overall look of the academic spaces can also be a significant factor in attracting potential first-year students and retaining students already on campus.

Landscaping. The land and buildings of a campus support the overall function of a college or university which is to promote quality education and research (Kärnä et al., 2013). The campus infrastructure can influence student, faculty and staff satisfaction. In addition, aesthetics and the overall campus appearance can influence the decision of potential students. Students seek colleges and universities they consider to be their home throughout their academic career. The appearance of an institution's campus can create an inviting environment. As colleges and universities invest in building and construction, one area of focus is landscaping.

The campus landscape can provide college and universities with a green space dedicated to environmental and ecological harmony (Wang, 2012). The landscape design can also provide a place for teachers and students to meet and study (Wang). Providing a green space on campus for students to relax or study can improve their overall quality of life (Hajrasouliha, 2017). The landscape can create an atmosphere which allows students to cope with the stress of college life, including social and academic 
challenges (Hajrasouliha). Investing in campus landscape supports a robust learning environment for faculty and students.

Student Facilities. Student facilities such as dining halls and recreational facilities contribute to the overall campus atmosphere. Due to increased competition, institutions attempt to draw students in with their unique and abundant amenities. Colleges and universities have upgraded from the traditional college food selections to now including Starbucks as well as other fancy meal plan options (Archibald \& Feldman, 2011). Recreational facilities such as gyms, pools and rock walls are now being built to entice students to enroll and reside on campus. These types of facilities can require unique types of repairs and maintenance services that may need to be outsourced to experienced third-party vendors. Students value the lifestyle and campus culture when making the decision regarding which school to attend.

\section{Student Financial Aid}

Typical financial resources provided by a college or institution, such as scholarships, to support student financial aid are classified as a reduction to tuition revenue rather than as a functional expense (FARM, para. 342.18). Scholarships that are awarded to students in excess of the amounts owed to the college or university by the students and are required to be refunded to the students are recorded under functional expenses (FARM, para. 342.18).

\section{Auxiliary Enterprises}

Functional expenses in this classification typically relate to auxiliary enterprises established to provide services to the college or university as well as the surrounding community (FARM, para. 342.20). These services are outside of the main mission of the college or university. The differentiating quality of an auxiliary enterprise relates to the fact that it is managed as a self-sustaining business unit (FARM, para. 342.20). Some examples are parking and housing for faculty-staff, health clinics and restaurants.

\section{Depreciation}

Depreciation represents an estimated expense related to the usage and wear on significant capital items such as buildings, furniture and equipment. The estimated useful lives of these items is determined by management of the college or university and the cost is typically written off over a period of time in an effort to approximate when the asset may need to be removed from service or be replaced. Depreciation is a significant estimate in college and university financial statements and can have some variations based upon geographical locations and various levels of use items incur.

\section{Financial Condition}

Public higher education institutions experience significant pressure of accountability for financial management given that they are owned by the state and partially funded by taxes imposed on its citizens (Sav, 2016). Recently, public colleges and universities endured another hurdle during the Great Recession - a significant decrease in state appropriations. From 2008 to 2013, state funding dropped from 32\% to $23 \%$ of total public college and university revenues (Sav, 2016).

The decrease in state funding has caused many public institutions to analyze their overall financial condition. In order to alleviate the financial strain brought on by a decline in state appropriations, some states have increased tuition rates, reduced financial aid and have frozen faculty salaries (Weerts, 2014). Long-term strategic plans rely first on the evaluation of financial condition. The first step is to understand the meaning of financial condition and then potential measurements.

\section{Definition}

Financial condition is a complex concept which can be affected by various factors, such as the fiscal structure and capacity of governmental entities, their potential challenges and future possibilities and financial techniques they implement (Ryu, Kim, \& Yang, 2017). "The Governmental Accounting Standards Board (GASB) defines a government's financial condition as 'a composite of a government's financial health and its ability and willingness to meet its financial obligations and commitments to provide services" 
(Clark, 2015, p. 66). The financial condition of public higher education institutions could be defined as its ability to provide educational degrees to students while tolerating economic downturns.

The healthier the financial condition of an institution the more likely it is to be able to continue to serve its students despite changes in the economy. Colleges and universities whose financial health is questionable, may need to re-evaluate their spending activity if they wish to survive in times of economic crisis. There are several measures which may be used to understand the financial condition of a public higher education institutions.

\section{Measurements}

Maher and Délier presented a paper at the 2012 Association for Budgeting and Financial Management (ABFM) conference titled, "Government-wide Statements as a Basis for Fiscal Condition Analysis: A Study of Wisconsin Counties," which analyzed the objective and subjective measurements of financial condition (Maher \& Deller, 2013). The measures of financial condition included the following descriptions and ratios (Maher \& Deller, 2013, p. 21):

Financial Position (unrestricted net assets/expenses)

Financial Performance (change in net assets/total net assets)

General Support Rate ([general revenues + transfers]/expenses)

Liquidity ([cash + current investments + receivables]/current liabilities)

Solvency (long-term debt/assets)

While each of these measurements may be used to determine an institution's overall financial status, the financial position ratio is widely used because it explains how many times an entity is able to pay its expenses.

The unrestricted net assets refers to the accumulated amount of additional revenues over expenditures in a governmental fund (Kelly, 2013). A fund-based analysis compares the fund revenues to fund expenditures (Maher \& Deller, 2013). Creditors, financial analysts and governmental agencies often use the net assets as an indicator of financial condition (Kelly).

\section{RESEARCH METHOD AND DESIGN}

The study was quantitative correlational and utilized multiple regression analysis to determine whether financial allocation ratios of functional expenditures can be used to predict financial condition.

\section{Method}

The study was quantitative given that it utilizes numbers to analyze relationships among the data (Creswell, 2014). Quantitative method was appropriate for the study because it included historical financial data from institutions within a state higher education system in the South Atlantic region of the United States. Qualitative research was not appropriate for the study because qualitative focuses on human perceptions and understanding (Stake, 2010), while this study analyzed objective financial data.

Data were gathered from the audited financial statements of each four-year institution within a state system institution in the South Atlantic region of the United States. Evaluation research was performed on the correlation between allocation ratios and financial condition for academic years 2008 through 2017. Unreserved fund balance and functional expense amounts for each year were summarized in an Excel spreadsheet and regression analysis performed in IBM SPSS software to determine whether any of the variables could predict an institution's financial condition.

\section{Research Design}

Correlational design is used in determining whether a relationship exists among variables (Morgan, Leech, Gloeckner, \& Barrett, 2013). Correlational design utilizing multiple regression analysis were used to analyze whether a correlation exists between changes allocation ratios of functional expense categories and financial condition of a selected number of four-year public higher education institutions. The objective of this study was to determine whether fluctuations in financial allocation ratios impact an institution's 
financial condition. The purpose was to find predictors of financial condition which institutions could utilize in their budgeting process.

"Regression analysis is a modeling technique for analyzing the relationship between a continuous (realvalued) dependent variable Y and one or more independent variables" (Ragsdale, 2015, p. 433). Multiple regression analysis includes more than one independent variable which can be added to the model to assess the combined effect of the predictors on the results (Pandis, 2016). The overall goal of regression analysis is to detect a function that describes the relationship among variables to predict the value of a dependent variable given certain values of the independent variables (Ragsdale). Because the objective of the study was to analyze the relationship between the independent variables (allocation ratios of functional expense categories) and the dependent variable (financial condition of an institution), multiple regression analysis was an appropriate research design.

\section{POPULATION AND SAMPLING}

The objective of the study was to determine whether variations in allocation ratios can predict financial condition of four-year public institutions across a single state system in the South Atlantic region of the United States. According to the Integrated Postsecondary Education Data System (IPEDS), there were 775 four-year or above public higher education institutions in the United States in 2017. The South Atlantic region, which consists of Delaware, Maryland, Virginia, West Virginia, North Carolina, South Carolina, Georgia, Florida and the District of Columbia, had a total of 149 four-year or above public higher education institutions in 2017 (IPEDS). A single state system in the South Atlantic region of the United States was chosen for the population of the study because the data were publicly and readily available on the state system's website. The sample included all four-year institutions within this particular state system. The sample included functional expense categories (excluding "other") from each institution over a ten-year period (2008-2017). Kelley and Maxwell (2003) explained that sample size, as it relates to multiple regression analysis "can be approached from at least four different perspectives: (a) power for the overall fit of the model, (b) power for a specific predictor, (c) precision of the estimate for the overall fit of the model, and (d) precision of the estimate for a specific predictor" (p. 306). The sample was considered appropriate for a quantitative study using multiple regression analysis because the entire population was being tested.

\section{DATA COLLECTION}

\section{Instruments}

The study culminated the data in a Microsoft Excel spreadsheet. Stout (2017) described Microsoft Excel as "a flexible and powerful tool" (para. 3) which can aide managers in planning and decision making. Once the data were summarized in Excel, they were imported into IBM Statistical Package of the Social Sciences (SPSS) version 25 software for analysis. The IBM SPSS software was used to perform multiple regression analysis on the variables selected to determine whether they could be used to predict financial condition. IBM SPSS is used to analyze large amounts of data and aide in the modelling process of "choosing and using appropriate mathematics and statistics to analyze empirical situations, to understand them better and to improve decisions" (Xiao, Xu, \& Xu, 2015). SPSS can be used to run a multiple regression analysis and also provide additional diagnostics. The analysis of variance (ANOVA) was also presented for each model that was determined to be a significant indicator of financial condition. Tables are included in the results section of the study.

\section{Data Collection Technique}

The data for this study included functional expense figures for all four-year institutions within a state system of higher education in the South Atlantic Region of the United States. This information was collected through the audited financial statements of each institution located on the state system's webpage. Any financial statements not provided on the state system's website was acquired through the individual 
school's website. Data were collected and summarized using Excel and then imported into IBM SPSS version 25 .

\section{DATA ANALYSIS TECHNIQUE}

This study investigated one null hypothesis: there are no statistically significant associations among allocation ratios of functional expenses and financial condition. Multiple linear regression analysis was used to test the hypothesis because there was a single dependent variable (financial condition) with multiple independent variables (allocation ratios of functional expense categories).

\section{Multiple Linear Regression}

Multiple regression analyzes two or more independent variables to determine whether they can predict results of a single dependent variable (Pandis, 2016). The dependent variable was financial condition for the multiple regression analysis. The measurement of this variable was scale. The independent variables were the allocation ratios of functional expenses. There were 10 initial functional expense categories tested: instruction, research, public service, academic support, student services, general institutional support, operations and maintenance of plant, student financial aid, auxiliary enterprises and depreciation. The allocation ratios in the study were computed by dividing a functional expenditure category by Total Operating Expenditures (TOE) to form a percentage of TOE. These variables were also scaled in nature as they were percentages. Analyzing the correlation between allocation ratios and financial condition addressed the research question: Is there a correlation between the allocation ratios of an institution, individually or in combination, and its financial condition? The null hypothesis related to this research question was there are no statistically significant associations among allocation ratios of functional expenses and financial condition. Because the null was an association question, the variables were scale and there were multiple independent variables, a multiple linear regression was used. The following steps were completed to perform the multiple linear regression:

1. Test assumptions of multiple linear regression. There are four assumptions of multiple regression: (1) the variables have a linear relationship with the dependent variable, (2) scores are normally distributed, (3) outliers are removed, and (4) issues of multicollinearity are eliminated (Morgan et al., 2013).

a. Scatterplots for each independent variable were visually inspected to determine linear functionality and detect outliers.

b. Descriptive statistics, including ranges, minimums, maximums, means, standard deviations and skewness will be performed for all the independent (allocation ratios of functional expenses) and dependent (financial condition) variables.

c. Pearson correlations were computed to examine the intercorrelations of the variables. Variables which are highly correlated (.50 or .60 and above) should either be combined into a single variable or one or more of the highly correlated variables may be eliminated if they do not provide meaningful data (Leech, Barrett, \& Morgan, 2005). The variables were examined for multicollinearity by first examining the Pearson coefficients with a positive correlation of $\geq .50$. If there were any issues of multicollinearity are noted, they were corrected prior to finalizing the model.

2. Determine the coefficient of determination $R$ and the proportion of shared variance $\left(R^{2}\right)$. The Pearson correlations was computed to determine the practical significance of the independent variable.

3. Determine whether the model was statistically significant. The p values were evaluated to determine whether the model was statistically significant.

4. Determine the relative importance of the predictor variables. In multiple regression, independent variables (functional expenditure allocation ratios) should demonstrate a high correlation with the dependent variable (financial condition), have low correlations among 
themselves and have a $\mathrm{p}$ value of less than .05 . In addition, the $\mathrm{R}^{2}$ should demonstrate that the independent variables contributed to the overall variance of the dependent variable.

\section{RELIABILITY AND VALIDITY}

\section{Reliability}

Reliability refers to the consistency of a measurement (Heale \& Twycross, 2015). An exact measurement of reliability cannot be calculated; however, reliability can be estimated using different measures (Heale \& Twycross). The data used for the study were the audited financial statements for all the four-year institutions within a state system of higher education over a 10-year period. This data were aggregated into the appropriate groups including various functional expense categories using required methods as prescribed by the Governmental Accounting Standards Board (GASB). The data in the study were subject to auditing procedures and reported under a required methodology which has been certified by an independent auditor. This information is publicly available and provides a financial data set which is not subjective in nature and allows others to potentially verify and replicate the study.

The reliability of the instruments refers to "the extent to which a research instrument consistently has the same results if it is used in the same situation on repeated occasions" (Heale \& Twycross, 2015, p. 66). The basic premise of the study relied on multiple regression analysis modeling which is an accepted mathematical calculation for analyzing variables in a data set. This methodology was acknowledged as a technique to predict an unknown variable from the known predictors. Because this study used a standard mathematical calculation that other researchers can replicate, it provides reliability to the study.

\section{Validity}

Ragsdale (2015) described a valid model as one which depicts the main attributes of the research questions surrounding the study. The validity of the internal attributes of the study were based upon comparable sets of financial information for similar periods from higher education institutions within the same state system of higher education. These schools were subject to the same allocation methodologies. The financial information was required to be reported in the same format across all schools. The financial statements were obtained from the state system website which has accumulated and provided comparable information for a significant period of years. This information is public information and has been opined on by certified public accountants as free from material misstatements.

The basic structure and methodology used for the study provided a logical approach because the uniform data used were subjected to rigorous testing to support its reliability and the mathematical calculations identified to analyze the data are commonly known and understood. This would support the overall validity of the study to external users.

External validity of the study was provided given the following factors: the study had a consistent time period of 10 fiscal years for data from each institution; a quantitative methodology was selected for the study which aligned with the financial data and calculations used in the study; the sample size of schools included in the study was suitable to achieve the desired outcome levels for the study; and finally the data used for the study was not manipulated or interpreted differently by others when the study was analyzed.

\section{PRESENTATION OF THE FINDINGS}

The percentage change in the 10 functional expense allocation ratios were hypothesized as possible predictors of financial condition. The single dependent variable of financial condition percentage and 10 functional expense allocation ratios were calculated for all four-year institutions in a state system in the South Atlantic region of the United States for 10 consecutive fiscal years (2008-2017). The hypothesis was addressed below. 


\section{H1: FINANCIAL CONDITION/FUNCTIONAL EXPENSE ALLOCATION RATIOS}

The hypothesis tested investigates whether an association exists between the allocation ratios of functional expense categories and the dependent variable of financial condition percentage. $\mathrm{H} 10$ states there are no statistically significant associations among allocation ratios of functional expenses and financial condition. "Associational inferential statistics test for associations or relationships between variables and use, for example, correlation or multiple regression analysis" (Leech et al., 2005, p. 5). Multiple regression is a complex associational statistic "used to predict a scale/normal dependent variable from two or more independent variables" (Morgan et al., 2015, p. 149). Descriptive statistics, scatterplots and evaluation of correlations to identify multicollinearity was used to determine that a multiple regression model was appropriate to test the hypothesis.

\section{Descriptive Statistics (10 Independent Variables)}

The data were first tested to meet the assumptions of multiple regression. According to Morgan et al. (2013), there are four assumptions of multiple regression: (1) the variables have a linear relationship with the dependent variable, (2) scores are normally distributed, (3) outliers are removed, and (4) issues of multicollinearity are eliminated. To begin, the scatterplots for each of the independent variables were visually inspected to determine linearity and detect outliers. The inspection revealed linear relationships for all independent; therefore, the Pearson correlation was the appropriate statistic for practical significance (Morgan et al.).

Next, descriptive statistics descriptive statistics were performed for all the independent variables (allocation ratios of functional expenses) and the dependent variable (financial condition). The ranges, minimums, maximums, means, standard deviations and skewness can be found on Table 6 in Appendix. $\mathrm{N}$ represents the number of samples - 100. Note that no data were omitted from any of the samples; therefore, the entire sample was included (10 institutions for 10 years). All the functional expenditure independent variables fall within a scale from $0 \%$ to $100 \%$; therefore, the mean and for all ten of these variables appears reasonable. The skewness of financial condition (1.977) and research (1.488) were higher than 1; however, if the skewness for each of these variables is divided by the standard error of .241 the result is less than 2.5 (which is the approximate level of $p=.01$; Morgan et al., 2013); therefore, the data appears to be normally distributed.

\section{Multicollinearity (10 Independent Variables)}

Because each of the ten independent variables was normally distributed and the assumption of linearity was not markedly violated, Pearson correlations were computed to examine the intercorrelations of the variables. According to Leech et al. (2005),

If variables are highly correlated (e.g., correlated at .50 or .60 and above), then one might decide to combine (aggregate) them into a composite variable or eliminate one or more of the highly correlated variables if the variables do not make a meaningful composite variable. (p.91)

The variables were examined for multicollinearity by first examining the Pearson coefficients with a positive correlation of $\geq .50$ on Table 7 (Appendix). One set of independent variables which appeared to be highly correlated with each other were Instruction and Academic Support with a coefficient of .674. Instruction is comprised mainly of faculty salaries and benefits which can be difficult to alter given the fact that they are based upon union contracts. Because of the nature of this category, it was eliminated from further analysis. Another set of independent variables which appear to be highly correlated are Research

and Public Service with a coefficient of .679. Since Research was not considered to be statistically significant ( $\mathrm{p}$ value of .056 which is greater than .05). It will be excluded from the second data set. The review for multicollinearity resulted in the elimination of two independent variables: Instruction and Research. 
As noted above, Instruction and Research were eliminated from the model due to issues of multicollinearity. The multiple regression analysis was rerun with the remaining eight independent variables. The variables were examined for multicollinearity by first examining the Pearson coefficients with a positive correlation of $\geq .50$ on Table 9 (Appendix). No further issues of multicollinearity were noted.

\section{Revised Model (7 Independent Variables)}

Because each of the eight independent variables noted above were normally distributed, the assumption of linearity was not markedly violated and there were no issues of multicollinearity, the Pearson correlations and $\mathrm{p}$ values were examined for practical and statistical significance (see Table 9 and Table 10 in Appendix). One variable, Depreciation, appeared to have a smaller than typical effect size $(r=.018)$. In addition, Depreciation was not statistically significant with a $\mathrm{p}$ value $>.05(\mathrm{p}=.430)$. Depreciation was not included in the final model because of its small effect size and it was not considered statistically significant. The multiple regression analysis was rerun with the seven remaining independent variables. No issues of multicollinearity were noted. See correlations below in Table 1.

\section{Practical Significance (7 Independent Variables)}

Because each of the seven independent variables were normally distributed, the assumption of linearity was not markedly violated, and no issues of multicollinearity were noted, Pearson correlations were computed to examine the practical significance of the variables. The Pearson Correlation is a common correlation statistic that is "calculated using an equation that relates two sets of scores for two different measures" (Emerson, 2015, p. 242) which results in the correlation coefficient. Table 1 provides the results of the correlations among all seven independent variables (functional expense allocation ratios) and the single dependent variable (financial condition).

Based upon the Pearson correlation coefficients in Table 1, general interpretation of the strength of the relationship between each of the independent variables and the dependent variable (financial condition) were noted in Table 2 below. Morgan et al. (2013) provides guidelines for five common effect size measures $(\mathrm{d}, \mathrm{r}, \varnothing, \mathrm{R}$ and $\eta$ ). For $\mathrm{r}$ and $\varnothing,|.10|$ is small or smaller than typical, $|.30|$ is medium or typical, $|.50|$ is large or larger than typical and $\geq|.70|$ is much larger than typical (Morgan et al.). Each of the independent variables were analyzed for their effect size and practical significance based upon this guidance. Note the findings in Table 2. 


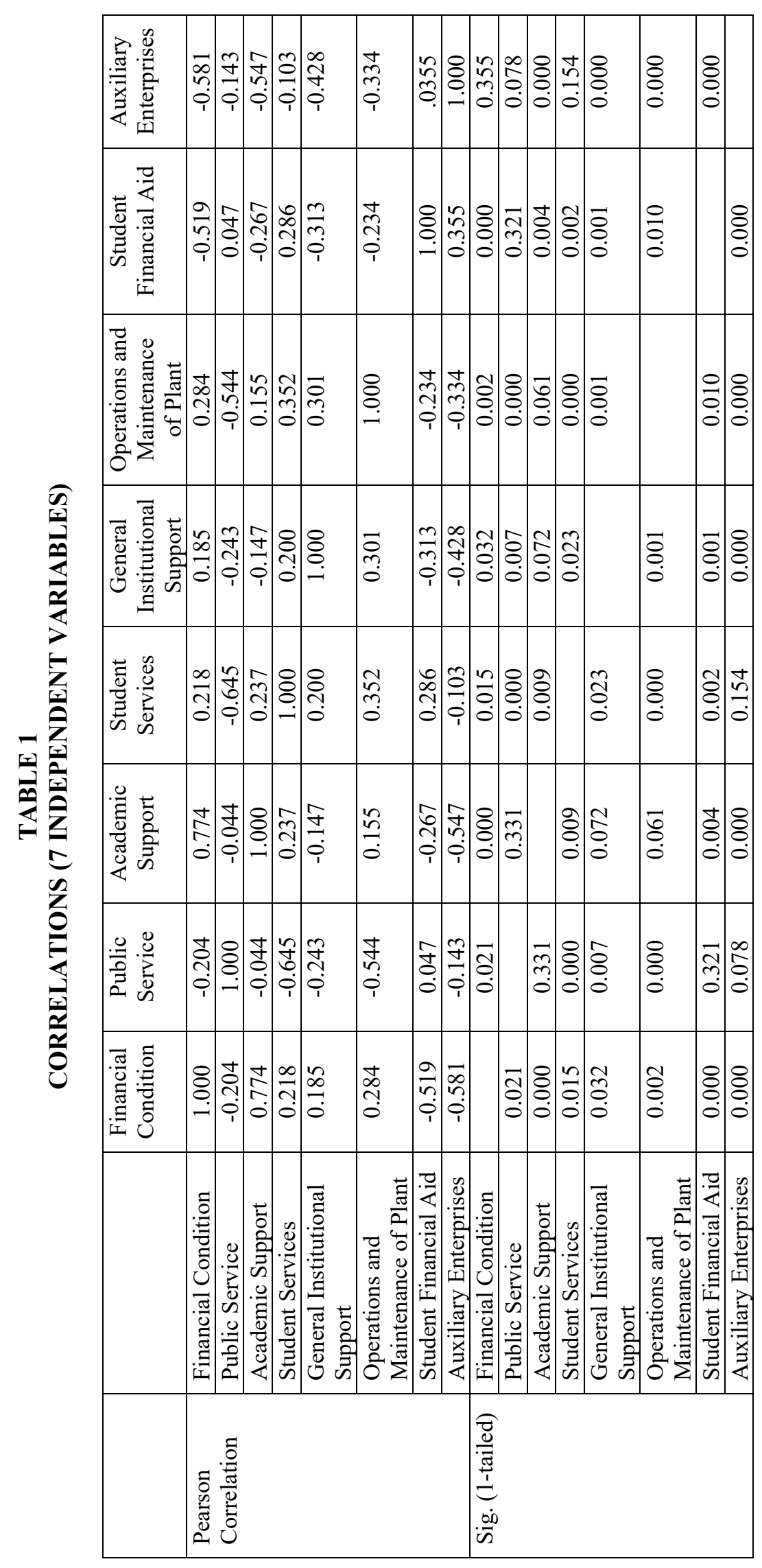

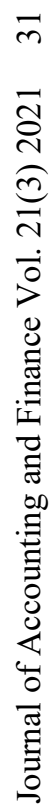


TABLE 2

INTERPRETATION OF RELATIONSHIPS - EFFECT SIZE (7 INDEPENDENT VARIABLES)

\begin{tabular}{ll}
\hline Independent Variables & Correlation with Financial Condition Percentage \\
\hline Public Service & Smaller than typical \\
Academic Support & Much larger than typical \\
Student Services & Smaller than typical \\
General Institutional Support & Smaller than typical \\
Operations and Maint. of Plant & Smaller than typical \\
Student Financial Aid & Larger than typical \\
Auxiliary Enterprises & Larger than typical \\
\hline
\end{tabular}

\section{Statistical Significance (7 Independent Variables)}

Next, to investigate the statistical significance of the independent variables with the dependent variable, the $\mathrm{p}$ values were analyzed from the correlations table (see Table 1). According to Morgan et al. (2013), the $p$ value represents a comparison of a calculated value to a critical value which describes the probability of rejecting a null hypothesis that is actually true. Typically, if the $\mathrm{p}$ value is $\leq .05$ the results are considered to be statistically significant (Morgan et al.). Based upon this criteria, all seven independent variables were considered to be statistically significant because they had a $\mathrm{p}$ value $<.05$.

\section{Model Summary (7 Independent Variables)}

The model summary (Table 3) and ANOVA (Table 4) was used to evaluate the significance of the model. This table presents the $\mathrm{R}^{2}$ and adjusted $\mathrm{R}^{2}(.740)$. The $\mathrm{R}^{2}$ signifies the proportion of the variance of financial condition that can be explained from the seven functional expense category allocation ratios. This indicates that $74 \%$ of the change in financial condition can be explained by the model.

\section{TABLE 3}

MODEL SUMMARY (7 INDEPENDENT VARIABLES)

\begin{tabular}{|c|c|c|c|c|c|c|c|c|}
\hline \multirow[t]{2}{*}{ Model } & \multirow[t]{2}{*}{$\mathbf{R}$} & \multirow{2}{*}{$\begin{array}{l}\text { R } \\
\text { Square }\end{array}$} & \multirow{2}{*}{$\begin{array}{l}\text { Adjusted } \\
\text { R Square }\end{array}$} & \multirow{2}{*}{$\begin{array}{l}\text { Std. Error of } \\
\text { the Estimate }\end{array}$} & \multicolumn{4}{|c|}{ Change Statistics } \\
\hline & & & & & $\begin{array}{l}\text { R Square } \\
\text { Change }\end{array}$ & $\begin{array}{l}\mathrm{F} \\
\text { Change }\end{array}$ & df1 df2 & $\begin{array}{l}\text { Sig. F } \\
\text { Change }\end{array}$ \\
\hline 1 & $.871^{\mathrm{a}}$ & 0.759 & 0.740 & $19.77385 \%$ & 0.759 & 41.318 & 92 & 0.000 \\
\hline
\end{tabular}

a. Predictors: (Constant), Auxiliary Enterprises, Student Services, General Institutional Support, Operations and Maintenance of Plant, Student Financial Aid, Academic Support, Public Service

b. Dependent Variable: Financial Condition

The ANOVA table (Table 4) shows the statistical significance of the regression test. The p value of the model is $<.000$. Since the $\mathrm{p}$ value is $<.05$, it indicates that the seven independent variables (functional expense allocation ratios) are statistically significant predictors of financial condition. 
TABLE 4

ANOVA (7 INDEPENDENT VARIABLES)

\begin{tabular}{lllllll}
\hline Model & Sum of Squares & df & Mean Square & F & Sig. \\
\hline $\mathbf{1}$ & Regression & 113089.726 & 7 & 16155.675 & 41.318 & $.000^{\mathrm{b}}$ \\
& Residual & 35972.466 & 92 & 391.005 & & \\
& Total & 149062.192 & 99 & & & \\
\hline
\end{tabular}

a. Dependent Variable: Financial Condition

b. Predictors: (Constant), Auxiliary Enterprises, Student Services, General Institutional Support, Operations and Maintenance of Plant, Student Financial Aid, Academic Support, Public Service

The coefficients table (Table 5) shows the standardized beta coefficients which are used to develop the regression equation noted in the results below.

TABLE 5

COEFFICIENTS (7 INDEPENDENT VARIABLES)

\begin{tabular}{|c|c|c|c|c|c|c|c|c|}
\hline \multirow{2}{*}{\multicolumn{2}{|c|}{ Model }} & \multicolumn{2}{|c|}{$\begin{array}{l}\text { Unstandardized } \\
\text { Coefficients }\end{array}$} & \multirow{2}{*}{$\begin{array}{l}\text { Standardized } \\
\text { Coefficients } \\
\text { Beta }\end{array}$} & \multirow[t]{2}{*}{$\mathbf{t}$} & \multirow[t]{2}{*}{ Sig. } & \multicolumn{2}{|c|}{$\begin{array}{l}95.0 \% \text { Confidence } \\
\text { Interval for B }\end{array}$} \\
\hline & & $\mathrm{B}$ & $\begin{array}{l}\text { Std. } \\
\text { Error }\end{array}$ & & & & $\begin{array}{l}\text { Lower } \\
\text { Bound }\end{array}$ & $\begin{array}{l}\text { Upper } \\
\text { Bound }\end{array}$ \\
\hline \multirow[t]{8}{*}{1} & (Constant) & -30.292 & 35.177 & & -0.861 & 0.391 & -100.156 & 39.573 \\
\hline & Public Service & -2.118 & 1.233 & -0.168 & -1.718 & 0.089 & -4.567 & 0.330 \\
\hline & $\begin{array}{l}\text { Academic } \\
\text { Support }\end{array}$ & 12.024 & 1.608 & 0.645 & 7.477 & 0.000 & 8.830 & 15.217 \\
\hline & Student Services & 0.486 & 2.028 & 0.021 & 0.240 & 0.811 & -3.541 & 4.513 \\
\hline & $\begin{array}{l}\text { General } \\
\text { Institutional } \\
\text { Support }\end{array}$ & 1.062 & 0.772 & 0.112 & 1.376 & 0.172 & -0.471 & 2.594 \\
\hline & $\begin{array}{l}\text { Operations and } \\
\text { Maintenance of } \\
\text { Plant }\end{array}$ & -1.083 & 1.457 & -0.054 & -0.743 & 0.459 & -3.977 & 1.811 \\
\hline & $\begin{array}{l}\text { Student Financial } \\
\text { Aid }\end{array}$ & -2.767 & 0.725 & -0.279 & -3.819 & 0.000 & -4.206 & -1.328 \\
\hline & $\begin{array}{l}\text { Auxiliary } \\
\text { Enterprises }\end{array}$ & -0.697 & 0.579 & -0.121 & -1.203 & 0.232 & -1.847 & 0.454 \\
\hline
\end{tabular}

\section{Results (7 Independent Variables)}

Simultaneous multiple regression was conducted to investigate the best prediction of financial condition of public higher education institutions within a state system located in the South Atlantic region of the United States. The combination of variables to predict financial condition from public service, academic support, student services, general institutional support, operations and maintenance of plant, student financial aid and auxiliary enterprises were statistically significant, $F(7,92)=41.32, p<.001$. The identified equation to understand this relationship was financial condition $=-30.29-2.12 \times$ (allocation ratio of public service) $+12.02 \times$ (allocation ratio of academic support) $+.49 \times$ (allocation ratio of student services) +1.06 $\mathrm{x}$ (allocation ratio of general institutional support) - $1.08 \mathrm{x}$ (allocation ratio of operations and maintenance of plant) $-2.77 \times$ (allocation ratio of student financial aid) - .70 x (allocation ratio of auxiliary enterprises). 
The adjusted $\mathrm{R}^{2}$ value was .740 which indicates that $74 \%$ of the variance in financial condition is explained by the model. Based on these findings, $\mathrm{H} 10$ which states there are no statistically significant associations among allocation ratios of functional expenses and financial condition is rejected. Public service, academic support, student services, general institutional support, operations and maintenance of plant, student financial aid and auxiliary enterprises are good indicators of financial condition at institutions within a state system located in the South Atlantic region of the United States.

For the research question, there was a statistically significant positive association between four independent variables (Academic Support, Student Services, General Institutional Support and Operations and Maintenance of Plant) and a statistically significant negative association between three independent variables (Public Service, Student Financial Aid and Auxiliary Enterprises) and the dependent variable of financial condition. There was not a statistically significant association between the remaining three independent variables (Instruction, Research and Depreciation) and financial condition.

Since public higher education institution's financial resources are finite, it is important to understand how to allocate those resource to reach optimal financial performance. Based upon the results above, investing in academic support, student services, general institutional support and operations and maintenance of plant has a statistically significant positive impact on an institution's financial condition. However, equally important is that investments in public service, student financial aid and auxiliary enterprises have a statistically significant negative influence on an institution's financial condition.

\section{APPLICATIONS TO PROFESSIONAL PRACTICE}

Effective resource allocation is a critical component of business process management and is recognized for its importance for process performance improvement (Zhao, Liu, Dai, \& Ma, 2016). A set of rules surrounding resource allocation is often implied; however, current approaches do not sufficiently draw conclusions surrounding the resource allocation rules (Huang, Lu, \& Duan, 2011). This study offers an initial methodology for public higher education institutions to use for resource allocation purposes. Analyzing the relationship between functional expense categories and financial condition reveals which functional areas are most influential on financial condition.

The results of this study may be used by the administration and board of directors of higher education institutions during strategic planning discussions as well as during the annual budget preparation. The budgeting process can be adjusted using the guidance of this study to make changes that could potentially be beneficial to the financial future of the institution.

The accounting industry can benefit from the outcomes of this study through improved allocation of expenditures during the budgeting process providing potentially stronger financial results of the institution. Accountants can use the predictive model to identify various areas for cost savings and reallocation of resources that can benefit the institution financially moving forward. One of the main goals for many accountants is to identify financial models and patterns that would assist in the budgeting process and help drive towards more profitable results for businesses and their owners, shareholders or trustees.

\section{RECOMMENDATIONS FOR ACTION}

Several conclusions were drawn from the study regarding correlations between changes in state appropriations, functional expenditure categories and an institution's financial condition.

\section{Functional Expense Categories}

The functional expense categories of an institution describe the various areas an institution may choose to invest its financial resources. The study initially analyzed the relationship between the allocation ratios of 10 functional expense categories and an institution's financial condition. Three of the functional expense categories did not have a strong correlation with financial condition (Instruction, Research and Depreciation). Since these were deemed not to be statistically significant, administrators and boards of trustees should not weigh them as heavily in the budgetary process of allocating resources. Seven of the 
functional expense categories showed a significant correlation to financial condition (Public Service, Academic Support, Student Services, General Institutional Support, Operations and Maintenance of Plant, Student Financial Aid and Auxiliary Enterprises). The recommendations on how to allocate resources to each of the categories is described below.

\section{Public Service}

Based upon the research, a negative correlation was present between public service and financial condition $(\mathrm{r}=-.204)$. As additional funds are allocated to public service, this would account for $10.2 \%$ of the overall impact in financial condition. The association between public service and financial condition was statistically significant as its $\mathrm{p}$ value was less than .05 .

Public service activities provide assistance to external constituencies from the institution (FARM, para. 342.13). Functional expenses included in this category consist of community service activities, support for hospitals, other non-profit entities and the surrounding community (FARM, para. 342.13). Public service continues to be a focus of higher education institutions going forward. The main issue for institutions is to carefully weigh the negative impact on financial condition related to public service with the surrounding community perception of the college as a partner contributing to the success of the local neighborhood.

Public service plays an integral component for any institution of higher education in the fact that participation increases awareness and engagement in the local community for students and faculty. Recognition for these types of service-oriented investments can provide positive media coverage and gain significant support from the local community which can also provide a method of attracting new students and bolster enrollment. However, based on the results of the study, additional investments in public service negatively impact an institution's financial condition.

\section{Academic Support}

A practical significant positive correlation $(r=.774)$ and statistically significant $(\mathrm{p}<.05)$ was noted between academic support and financial condition. An increase in academic support represents approximately $38.7 \%$ of the total increase in financial condition. Based upon this information, those involved in strategic planning for public higher education institutions should consider additional investment opportunities in the academic support functional expenditure category.

Academic support encompasses expenses related to an institution's overall missions: instruction, research and public service (FARM, para. 342.14). It includes the following subcategories: libraries, museums and galleries, educational media services, academic support informational technology, ancillary support, academic administration, academic professional development and course and curriculum development. The data could be shared with the campus community to support faculty and staff requests for funding which enhances the classroom and learning experience.

\section{Student Services}

Student services displayed a statistically significant $(\mathrm{p}<.05)$ positive correlation to financial condition $(\mathrm{r}=.218)$. Increases to student services expenditures would relate to nearly $11 \%$ of the overall increase in financial condition.

Functional expenses related to student services mainly provide support for the students' physical, emotional and intellectual well-being outside of academics (FARM, para. 342.15). Admissions, financial aid and student life/activities represent the more significant subcategories of student services (FARM, para. 342.15). Social and cultural development is an important component of student life/activities and can consist of various intramural and intercollegiate athletic teams, an array of student organizations as well as outdoor leadership activities.

Many colleges and universities have identified the benefit of investing financial resources in student services. As the competition to attract new students continues to heighten, investments in areas such as admissions and athletics have been implemented and based upon the results of the study, have made a positive impact on the overall financial condition of the entity. 


\section{General Institutional Support}

The results of the correlation testing at Table 9 indicate a statistically significant $(\mathrm{p}<.05)$ positive correlation between general institutional support and financial condition $(\mathrm{r}=.185)$. As general institutional support increases, this would account for $9.25 \%$ of the total increase in financial condition.

General institutional support references expenditures for strategic initiatives and long-term planning for the entire institution (FARM, para. 342.16). This functional expense classification is an important category as it relies on various areas such as administrative informational technology and development, fiscal operations, executive management of the college and overall general administration (FARM, para. 342.16).

The overall vision and strategic plan of the college or university plays a significant role in the direction and future of the institution. By choosing to invest additional resources in this area, institutions can be proactive related to their future success by implementing comprehensive strategic plans which allow for improved financial condition.

\section{Operations and Maintenance of Plant}

A positive correlation that is statistically significant $(\mathrm{p}<.05)$ exists between operations and maintenance of plant with financial condition $(\mathrm{r}=.284)$. An increase in spending related to operations and maintenance of plant would account for around $14 \%$ of the total increase in financial condition.

Operations and maintenance of plant expenditures pertain to the overall repair, management and supervision of the physical plant of the college (FARM, para. 342.17). Many of the expenditures related to this functional expense category deal with overall maintenance and repairs to facilities and equipment on campus, cleaning and upkeep related to buildings and grounds, housekeeping services for cleaning of residence halls and academic spaces, utilities, hazardous waste disposal and management/oversight of new construction as well as campus renovations (FARM, para. 342.17).

Institutions of higher education strive to be proactive related to the operations and maintenance of plant to leverage financial resources as much as possible to create the most significant upgrades to facilities and grounds to attract and retain students. The overall perception of campus is an important quality that most potential students and their families use to assist in their selection of their future college.

\section{Student Financial Aid}

Student financial aid has a statistically significant $(\mathrm{p}<.05)$ inverse relationship with financial condition $(\mathrm{r}=-.519)$. This relationship expresses that an increase in student financial aid accounts for approximately $26 \%$ of the total decrease in financial condition.

Student financial aid has been an area of significant scrutiny during recent years. Higher education institutions must weigh the financial impact of awarding additional financial aid to students that allow families to feel that a college education is affordable and worthy of the investment. The study shows institutions that continue to enhance financial aid packages to attract additional students negatively impact the future financial condition of the institution.

Students and families could be affected by this information as institutions may decide to reduce the amount of student financial aid offered. State officials may need to analyze the data to ensure that quality education remains affordable to its residents.

\section{Auxiliary Enterprises}

The auxiliary enterprises allocation ratio has an inverse relationship with financial condition $(\mathrm{r}=-.581)$. Increasing funding in auxiliary enterprises indicates approximately $29 \%$ of the total decrease in financial condition. Budget officers and strategic planning committees should contemplate reducing the amount of funds invested in auxiliary enterprises because of its inverse relationship to financial condition.

Functional expenses classified as auxiliary enterprises refer to services outside the main mission of the institution with the purpose of providing services to the college or university and surrounding community (FARM, para. 342.20). These activities are run as a separate business unit and include parking, housing, health clinics and restaurants (FARM, para. 342.20). 
Not only does this information impact staff at these auxiliary enterprises, but it could also influence citizens in the surrounding community. Individuals seeking medical attention at health clinics or customers of restaurants could be affected by a decision to reduce funding to these business units. However, since these activities are not related to an institution's primary mission, administrators must consider whether they should continue to fund these auxiliary enterprises given the results of the study.

\section{RECOMMENDATIONS FOR FURTHER STUDY}

Research into predictors of financial condition is an important component of an entity's sustainability. Understanding which areas of investment contribute to the financial stability of an institution or organization could potentially change the budgeting process and improve business practices. Organizations who utilize this information can gain a competitive advantage in the global marketplace.

This study examined the correlation among the percentage change in allocation ratios of functional expense categories and financial condition of all the four-year higher education institutions of a state system located in the South Atlantic region of the United States. There are several areas for further research which can supplement the information presented above and increase the reliability of the study.

The model presented could be extended to include the breakdown within each of the functional expense categories, such as salaries and wages, benefits, supplies and other services and utilities, rather than only the totals. The data are also available in the financial statements. This information could provide a more in depth understanding of which subcategories correlate to the financial condition of an institution.

Expanding the model to include other state systems institutions across the United States or even to private institutions could further identity whether a correlation exists between allocation ratios among functional expense categories and an institution's financial condition.

The current study focuses on allocation ratios as an indicator of financial condition; however, other qualitative factors may also play an important role in financial condition. Qualitative factors, such as geographical location, number of academic program offerings, student body demographics, accreditation, etc., could potentially be strong indicators of financial condition.

While this study focused on the financial condition of public higher education institutions, there are other indicators which define the success of an institution. For instance, further research could investigate how allocation ratios of functional expense categories may impact student academic performance. The primary mission of a higher education institution is to educate its students; therefore, focusing on student success may be meaningful.

The research could also be extended beyond the higher education sector and applied to other business industries - manufacturing, healthcare, non-profit, retail. Any business entity could benefit from identifying areas of resource allocation which correlate to financial condition.

\section{SUMMARY AND STUDY CONCLUSIONS}

Higher education is facing a paradigm shift in their business model. As state appropriations are reduced, the number of college going students in various geographical areas have decreased and the affordability of a college education has become a significant issue for students and their families, institutions must identify improved ways to analyze their financial models and budgeting processes in order to insure their future sustainability.

This study provides insight into the relationships between financial condition and functional expenses for institutions of higher education. The results of the model can be used to assist administrators in higher education with future budgeting strategies that can position their institutions for financial viability into the future. 


\section{REFERENCES}

Altundemir, M.E. (2012). The impact of the financial crisis on American public universities. International Journal of Business and Social Science, 3(8), 190-198.

Aquije, O. (2011). Most community colleges say building dorms is a good plan. The Post Star. Retrieved from http://poststar.com/news/local/most-community-colleges-say-building-dorms-is-goodplan/article_86314b5c-c61b-11e0-bfec-001cc4c03286.html

Archibald, R.B., \& Feldman, D.H. (2011). Are Plush Dorms and Fancy Food Plans Important Drivers of College Cost? Change, 43(1), 31-37. doi: 10.1080/00091383.2011.538649

Austin, A.E., \& Sorcinelli, M.D. (2013). The future of faculty development: Where are we going? New Directions for Teaching and Learning, 2013(133), 85-97. doi: 10.1002/t1.20048

Bransberger, P., \& Michelau, D.K. (2016). Knocking at the college door: Projections of high school graduates. Western Interstate Commission for Higher Education.

Broadhurst, J. (2012). Employee development is a great business opportunity. Human Resource Management International Digest, 20(6), 27-30. doi: 10.1108/0967073121126086

Carpenter, R., Sweet, C., \& Blythe, H. (2016). The future of faculty development. The Journal of Faculty Development, 30(2), 5-8.

Chay Hoon, L., \& Bruvold, N.T. (2003). Creating value for employees: Investment in employee development. International Journal of Human Resource Management, 14(6), 981-1000. doi:10.1080/0958519032000106173

Cheskis-Gold, R., \& Danahy, A.D. (2012). Trends in student housing: Process and product. Planning for Higher Education, 41(1), 245-264.

Clark, B.Y. (2015). Evaluating the validity and reliability of the financial condition index for local governments. Public Budgeting \& Finance, 35(2), 66-88.

Creswell, J.W. (2014). Research design: Qualitative, quantitative, and mixed methods approaches (4th ed.). Thousand Oaks, CA: Sage.

Daly, S. (2013). Philanthropy, the new professionals and higher education: The advent of directors of development and alumni relations. Journal of Higher Education Policy and Management, 35(1), 21-33. doi: 10.1080/1360080X.2012.727701

Dee, J.R., \& Heineman, W.A. (2016). Understanding the organizational context of academic program development. New Directions for Institutional Research, 2015(158), 9-35. doi: 10.1002/ir.20158

Emerson, R.W. (2015). Causation and Pearson's correlation coefficient. Journal of Visual Impairment \& Blindness (Online), 109(3), 242.

Farber, M. (2016). College enrollment dips as more adults ditch degrees for jobs. Fortune. Retrieved from http://fortune.com/2016/12/19/college-enrollment-decline/

Felix, E., \& Lerner, C. (2017). The why, what, when, where, and how of student service innovation. Planning for Higher Education, 45(2), 54-64.

Ford, M. (2017). The functions of higher education. American Journal of Economics and Sociology, 76(3), 559-578. doi: 10.1111/ajes.12187

Gansemer-Topf, A., Von Haden, K., \& Peggar, E. (2014). Aligning competencies with success: What does it take to be an effective admissions counselor. College and University, 90(1), 14-22.

Hajrasouliha, A. (2017). Campus score: Measuring university campus qualities. Landscape and Urban Planning, 158, 166-176. doi: 10.1016/j.landurbplan.2016.10.007

Heale, R., \& Twycross, A. (2015). Validity and reliability in quantitative studies. Evidence-Based Nursing, 18(3), 66-67. doi: 10.1136/eb-2015-102129

Huang, Z., Lu, X., \& Duan, H. (2011). Mining association rules to support resource allocation in business process management. Expert Systems With Applications, 38(8), 9483-9490. doi: 10.1016/j.eswa.2011.01.146

Jensen, R., \& Winters, J. (2012). Two campus housing master plans, one planning process. Planning for Higher Education, 41(1), 347-354. 
Jones, S., Lefoe, G., Harvey, M., \& Ryland, K. (2012). Distributed leadership: A collaborative framework for academics, executives and professionals in higher education. Journal of Higher Education Policy and Management, 34(1), 67-78. doi: 10.1080/1360080X.2012.642334

Kärnä, S., \& Julin, P. (2015). A framework for measuring student and staff satisfaction with university campus facilities. Quality Assurance in Education, 23(1), 47-66. doi: 10.1108/QAE-10-20130041

Kärnä, S., Julin, P., \& Nenonen, S. (2013). User satisfaction on a university campus by students and staff. Intelligent Buildings International, 5(2), 69-82. doi: 10.1080/17508975.2013.778810

Kelley, K., \& Maxwell, S.E. (2003). Sample size for multiple regression: Obtaining regression coefficients that are accurate, not simply significant. Psychological Methods, 8(3), 305-321. doi: 10.1037/1082-989X.8.3.305

Kelly, J.M. (2013). Fund balance for budget stabilization: Does the new accounting presentation matter? Journal of Public Budgeting, Accounting \& Financial Management, 25(4), 719-737.

Kempton, L.M. (1996). Allocation ratios as predictors of financial condition in Michigan K-12 school districts (Order No. 9711910). Available from ProQuest Dissertations \& Theses Global. (304318149). Retrieved from http://ezproxy.liberty.edu/login?url=https://search-proquestcom.ezproxy.liberty.edu/docview/304318149?accountid=12085

Kengatharan, L. (2016). Capital budgeting theory and practice. Applied Economics and Finance, 3(2), 15-38. doi: 10.11114/aef.v3i2.1261

Khasawneh, S. (2011). Human capital planning in higher education institutions: A strategic human resource development initiative in Jordan. International Journal of Educational Management, 25(6), 534-544. doi: 10.1108/09513541111159040

Kibirige, H.M., \& DePalo, L. (2001). The education function in a digital library environment: A challenge for college and research libraries. The Electronic Library, 19(5), 283-295.

Klein, M. (2015). Settling a U.S. senatorial debate: Understanding declines in state higher education funding. Journal of Education Finance, 41(1), 1-29.

Leather, D.J., \& Marinho, R.D. (2009). Designing an academic building for 21st-century learning: A dean's guide. Change: The Magazine of Higher Learning, 41(3). doi: 10.3200/CHNG.41.3.42-49

Leech, N.L., Barrett, K.C., \& Morgan, G.A. (2005). SPSS for intermediate statistics (2nd ed.). Mahwah, NJ: Lawrence Erlbaum Associates.

Lowenthal, P.R., Wray, M.L., Bates, B., Switzer, T., \& Stevens, E. (2012). Examining faculty motivation to participate in faculty development. International Journal of University Teaching and Faculty Development, 3(3), 149-164.

Maher, C.S., \& Deller, S.C. (2013). Assessing the relationship between objective and subjective measures of fiscal condition using government-wide statements. Public Budgeting \& Finance, 33(3), 115136. doi: 10.1111/j.1540-5850.2013.12017.x

Marks, L.I., \& Wade, J.C. (2015). Positive psychology on campus: Creating the conditions for well-being and success. About Campus, 19(1), 9-15. doi: 10.1002/abc.21174

McBride, Y. (2017). Future of student housing: Meeting emerging student needs. On the Horizon, 25(3), 190-196. doi: 10.1108/OTH-05-2017-0026

McGill, M.M., \& Settle, A. (2012). Identifying effects of institutional resources and support on computing faculty research productivity, tenure, and promotion. International Journal of Doctoral Studies, 7, 167-198.

McKinney, L., \& Roberts, T. (2012). The role of community college financial aid counselors in helping students understand and utilize financial aid. Community College Journal of Research and Practice, 36(10), 761-774. doi: 10.1080/10668926.2011.585112

Mello, J.A. (2015). Strategic human resource management (4th ed.). Mason, OH: South-Western.

Mintrom, M. (2008). Managing the research function of the university: Pressures and dilemmas. Journal of Higher Education Policy and Management, 30(3), 231-244. doi: 10.1080/13600800802155028

Mitchell, M., Palacios, V., \& Leachman, M. (2014). States are still funding education below prerecession levels. Washington DC: Center on Budget and Policy Priorities. 
Morgan, G.A., Leech, N.L., Gloeckner, G.W., \& Barrett, K.C. (2013). IBM SPSS for introductory statistics (5th ed.). New York, NY: Routledge, Taylor \& Francis Group.

Nafukho, F. (2009). HRD's role in identifying, measuring, and managing knowledge assets in the intangible economy. Advances in Developing Human Resources, 11(3), 399-410. doi: $10.1177 / 1523422309337718$

Ness, E.C., \& Tandberg, D.A. (2013). The determinants of state spending on higher education: How capital project funding differs from general fund appropriations. The Journal of Higher Education, 84(3), 329-362. doi: 10.1353/jhe.2013.0016

Palmer, J.C. (2014). Budgeting approaches in community colleges. New Directions for Community Colleges, 2014(168), 29-40. doi: 10.1002/cc.20118

Pandis, N. (2016). Multiple linear regression analysis. American Journal of Orthodontics and Dentofacial Orthopedics, 149(4), 581. doi: 10.1016/j.ajodo.2016.01.012

Phillips, C.R., \& Olson, J.E. (2015). To what extent are the final cost objectives of universities subsidized? Review of Business, 36(1), 113-129.

Powell, K.K., \& Rey, M.P. (2015). Exploring a resource dependency perspective as an organizational strategy for building resource capacity. Management in Education, 29(3), 94-99. doi:10.1177/0892020615586805

Ragsdale, C.T. (2015). Spreadsheet modeling \& decision analysis: A practical introduction to business analytics (7th ed.). Stamford, CT: Cengage Learning.

Roberts, P., \& Taylor, I. (2016). The campus matters: Acquiring the competitive edge. Planning for Higher Education, 44(3), 12-17.

Ryu, D., Kim, H., \& Yang, H. (2017). Investor sentiment, trading behavior and stock returns. Applied Economics Letters, 24(12), 826-830.

Sav, G.T. (2016). Declining state funding and efficiency effects on public higher education: Government really does matter. International Advances in Economic Research, 22(4), 397-408. doi: $10.1007 / \mathrm{s} 11294-016-9602-\mathrm{z}$

Severns, R. (2012). Higher education in times of financial distress: The Minnesota experience. Journal of College Teaching \& Learning, 9(2), 115-120.

Stake, R.E. (2010). Qualitative research: Studying how things work. New York, NY. Guilford Publications.

Staton, M. (2014). Universities are missing out on an explosive growth sector. Harvard Business Review. Retrieved from https://hbr.org/2014/06/universities-are-missing-out-on-an-explosive-growthsector-their-own/

Stout, D.E. (2017). Using excel 2013 for regression-based cost estimation: Part 1. Management Accounting Quarterly, 18(2).

Tietjen, D. (2015). Down and out of the dorm. Forbes. Retrieved from http://www.forbes.com/sites/denalitietjen/2015/07/31/off-campus-housing/\#1f24c8c4371f

Voorhees, W.R., \& Kravchuk, R.S. (2002). The new governmental financial reporting model under GASB statement no. 34: An emphasis on accountability. Public Budgeting \& Finance, 21(3), 130. doi: $10.1111 / 0275-1100.00040$

Wang, S.Y. (2012). The construction of campus with growth and open landscape - Linyi University new campus landscape planning. Applied Mechanics and Materials, 174-177, 2563-2566. doi: 10.4028/www.scientific.net/AMM.174-177.2563

Weerts, D.J. (2014). State funding and the engaged university: Understanding community engagement and state appropriations for higher education. The Review of Higher Education, 38(1), 133-169. doi: $10.1353 /$ rhe.2014.0038

Weerts, D.J., \& Ronca, J.M. (2012). Understanding differences in state support for higher education across states, sectors, and institutions: A longitudinal study. The Journal of Higher Education, 83(2), 155-185. doi: 10.1353/jhe.2012.0012

Woodhouse, K. (2015). Closures to Triple. Inside Higher Ed. Retrieved from https://www.insidehighered.com/news/2015/09/28/moodys-predicts-college-closures-triple-2017 
Xiao, X., Xu, H., \& Xu, S. (2015). Using IBM SPSS modeler to improve undergraduate mathematical modelling competence. Computer Applications in Engineering Education, 23(4), 603-609. doi: $10.1002 /$ cae. 21632

Zhang, L., Yu, X., Yang, Z., \& Du, Q. (2014). Human capital planning of faculties in higher education institutions with analytic hierarchy process model. Journal of Human Resource and Sustainability Studies, 2014(2), 224-229. doi: 10.4236/jhrss.2014.24023

Zhao, W., Liu, H., Dai, W., \& Ma, J. (2016). An entropy-based clustering ensemble method to support resource allocation in business process management. Knowledge and Information Systems, 48(2), 305-330. doi: 10.1007/s10115-015-0879-7 


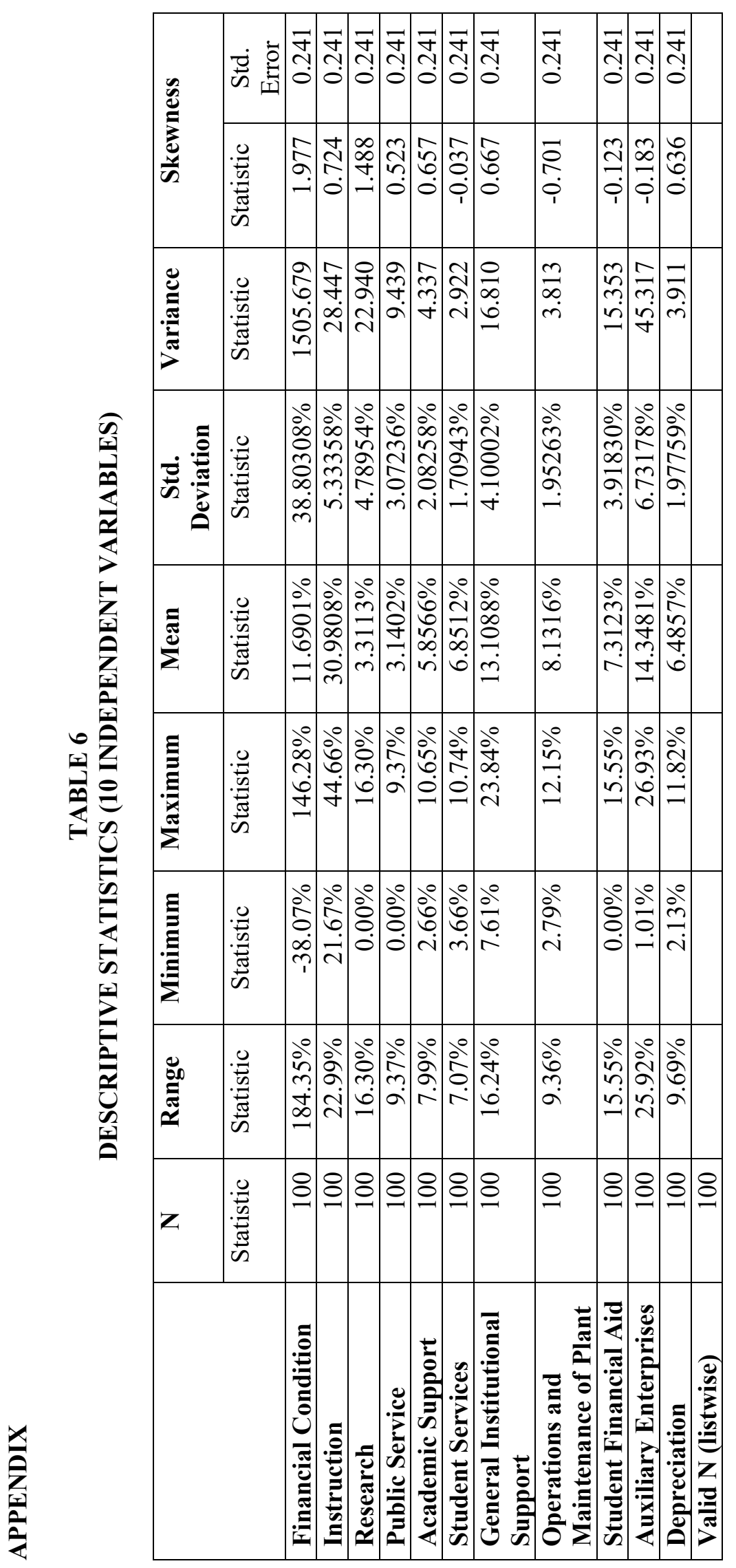

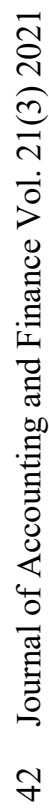




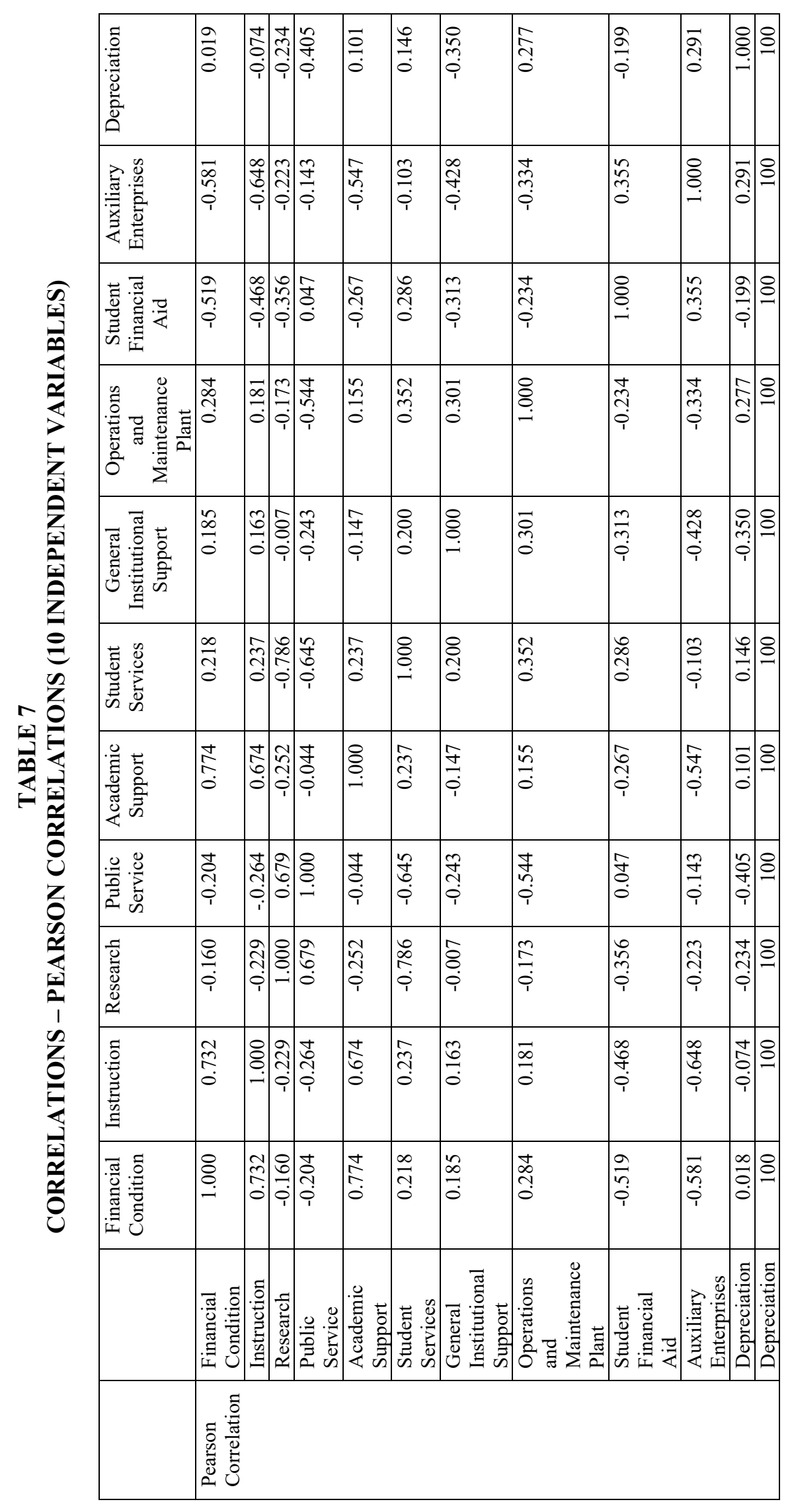

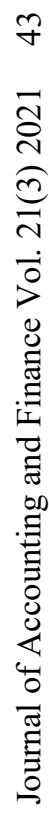




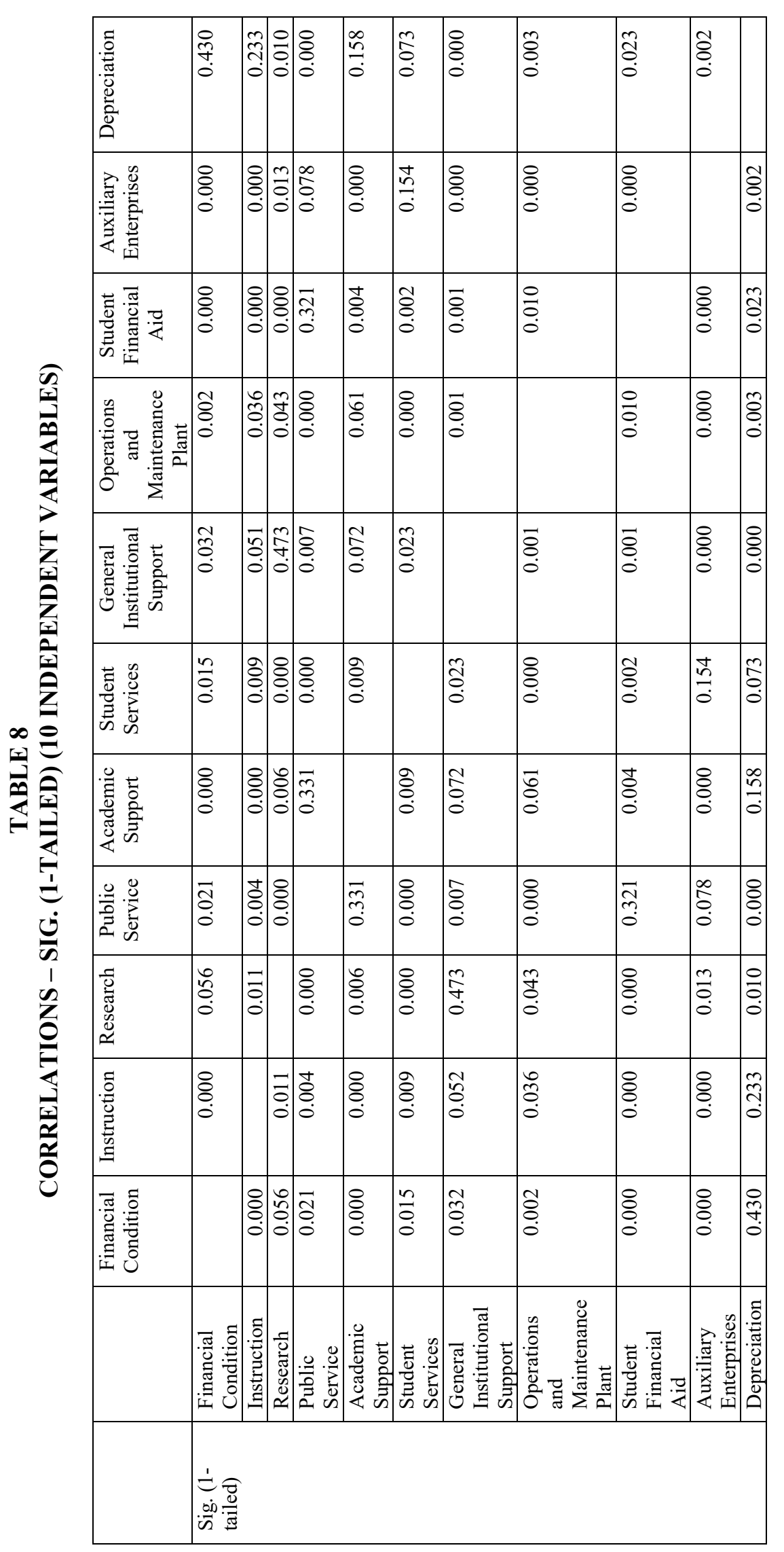

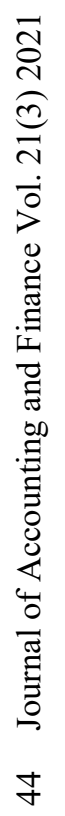




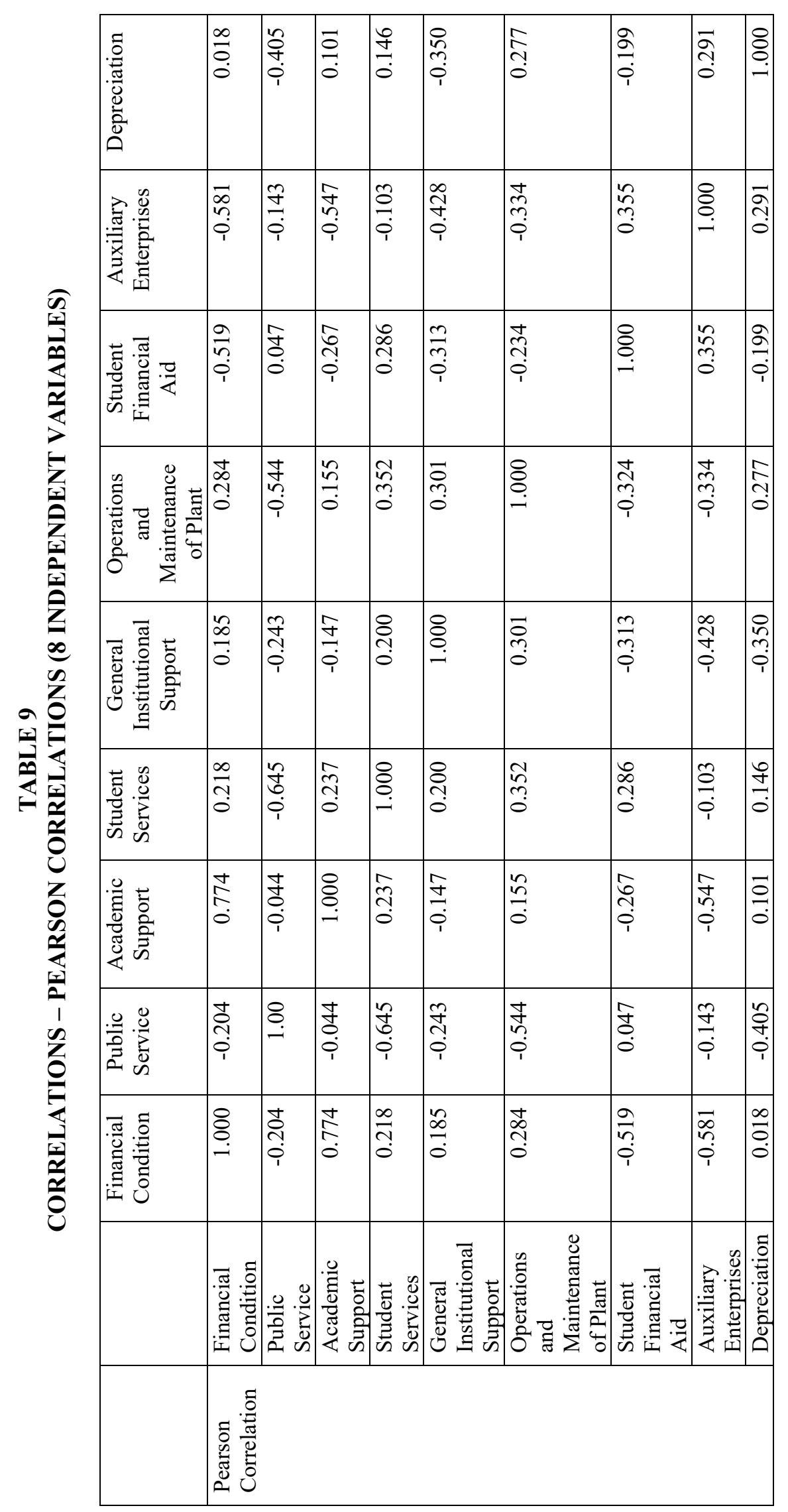

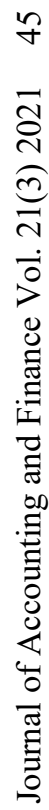




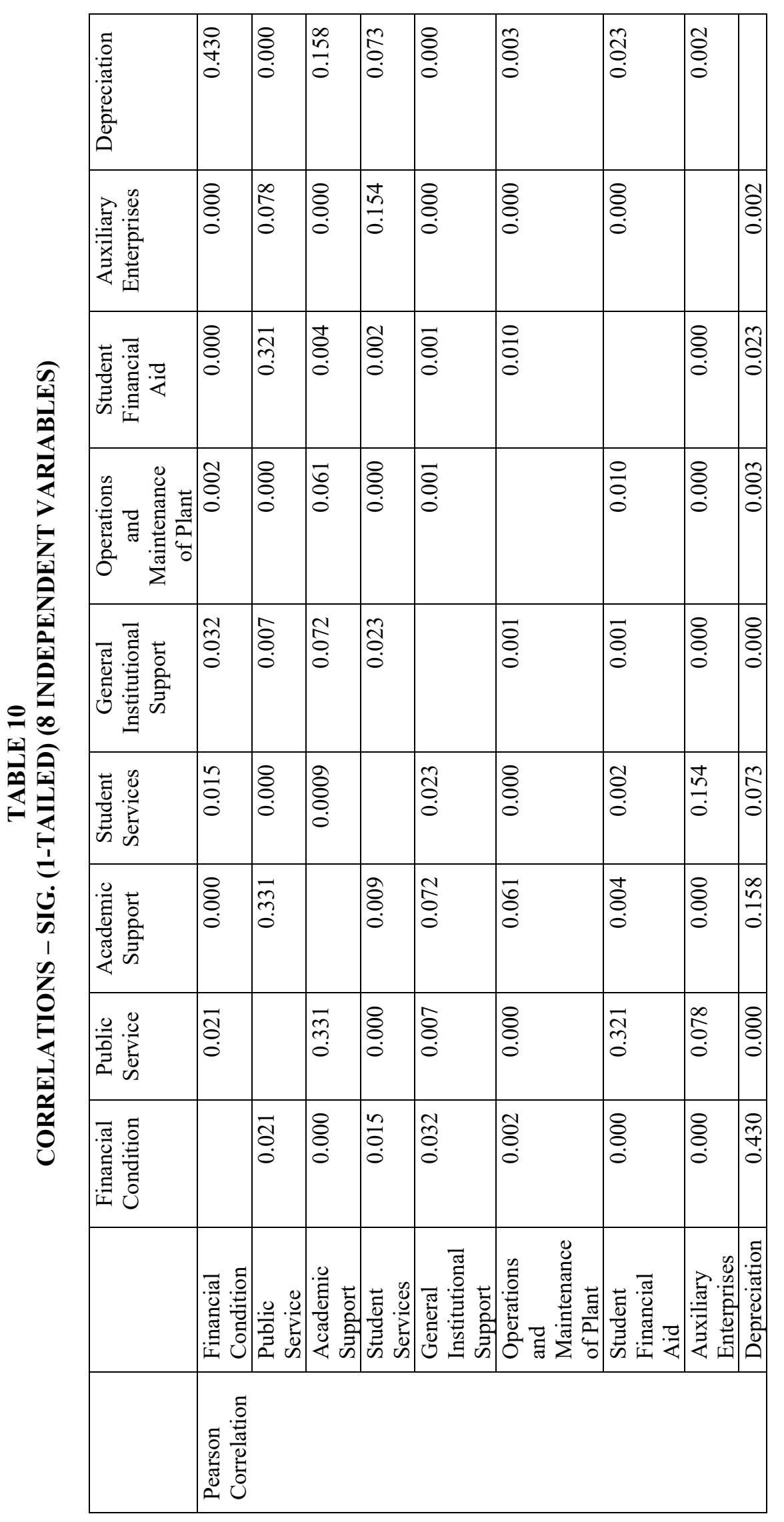

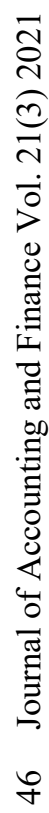

